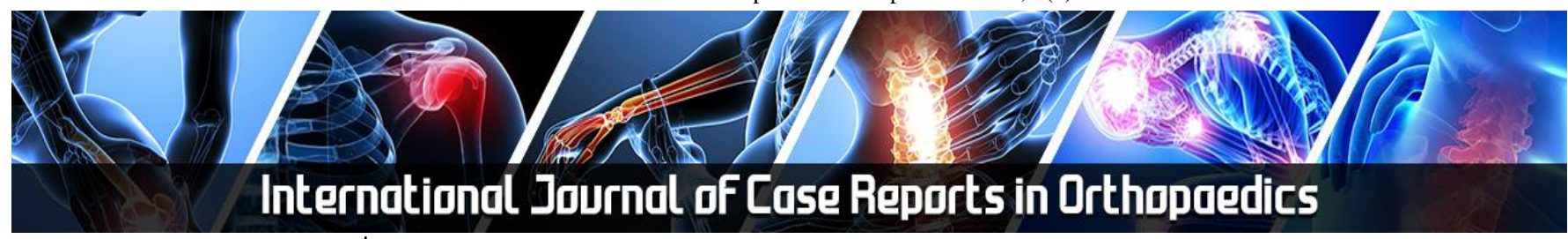

E-ISSN: 2707-8353 P-ISSN: 2707-8345 IJCRO 2021; 3(1): 65-68 Received: 11-12-2020 Accepted: 05-01-2021

Dr. Rajesh K Ambulgekar H.O.D., Department of Orthopedics, Drsegme, Nanded, Maharashtra, India

Dr. Mahesh P Deshmukh Junior Resident, Department of Orthopedics, Drscgmc, Nanded, Maharashtra, India
Corresponding Author: Dr. Mahesh P Deshmukh Junior Resident,

Department of Orthopedics, Drscgme, Nanded,

Maharashtra, India

\section{Case of Recurrence of 8 years back operated case of benign Giant Cell Tumor of the proximal Tibia with malignant fulminating mass over upper one third of leg}

\author{
Dr. Rajesh K Ambulgekar and Dr. Mahesh P Deshmukh
}

DOI: https://doi.org/10.22271/27078345.2021.v3.i1b.49

\begin{abstract}
Giant cell tumor is a locally aggressive benign tumor of bone predominantly involving proximal tibia region. We are reporting Case of Recurrence of 8years back operated case of Giant Cell Tumor of the proximal Tibia previously treated with cementing and bone grafting now presented with malignant fulminating mass over upper one third of leg managed with amputation.
\end{abstract}

Keywords: Giant cell tumor, Recurrence, proximal tibia, malignant fulminating mass

\section{Introduction}

Giant cell tumors are common in proximal tibia and distal end radius and have a low tendency to recur. They have been treated successfully with excision and cementing or sandwich bone grafting without recurrence. GCT represents approximately $5 \%$ of all primary bone tumors ${ }^{[2,3]}$. More than half of these lesions occur in the third and fourth decades of life [3]. GCTs are benign tumors with potential for aggressive behavior and capacity to metastasize. Although considered to be benign tumors of bone, GCT has a relatively high recurrence rate. Metastases occur in 1-\% of patients with GCT and some earlier studies have correlated the incidence of metastases with aggressive growth and local recurrence ${ }^{[4,5] .90 \%}$ of GCT exhibits the typical epiphyseal location ${ }^{[6,7]}$. The most common locations, in decreasing order, are the distal femur, the proximal tibia, the distal radius, and the sacrum ${ }^{[8]}$. Involvement of the foot and ankle is rare and comprises $<4 \%$ of all giant cell tumors (GCT) ${ }^{[9]}$. We present this of GCT in the proximal tibia recurring after treatment which was treated successfully with no signs of recurrence this time with amputation.

\section{Case Report}

A 40-year-old female presented with complaints of pain and swelling and deformity below right knee since 4 month. 4 month back patient developed cystic swelling just below right knee which was insidious in onset and proliferating in nature. Now patient came with fungating soft tissue mass just below right knee. There was no history of trauma. Patient had history of GCT 8 yrs back which was treated with saucerisation and bone grafting cementing.

On examination, lobulated outgrowing fungating mass over anterior aspect of proximal $1 / 3$ rd of leg of size 10x10x7 cm. Surface is ulcerative with clear and darkened margins due to pigmentation. Surrounding skin appeared reddish brown. On palpation local raise of temperature and tenderness present, mass not attached to underline bone \& surface is ulcerative, distal pulses and movement present $\&$ lymph nodes are not palpable. 

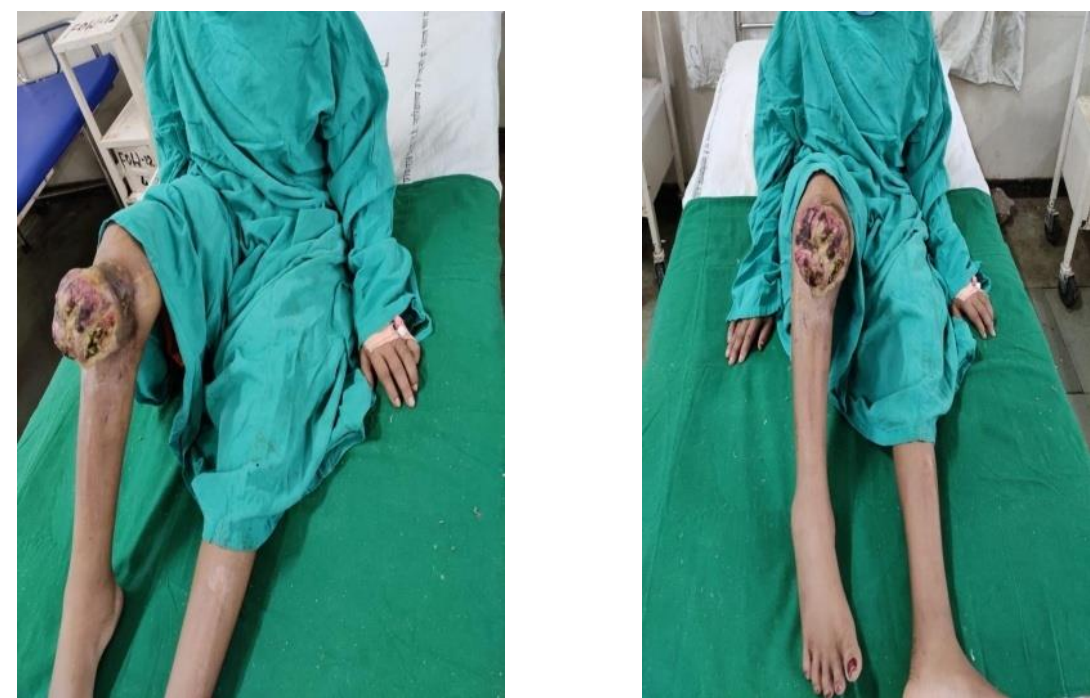

Fig 1: Clinical picture of patient

$\mathbf{X}$-rays revealed a mass over proximal tibia with opacity inside proximal tibia with cementing.
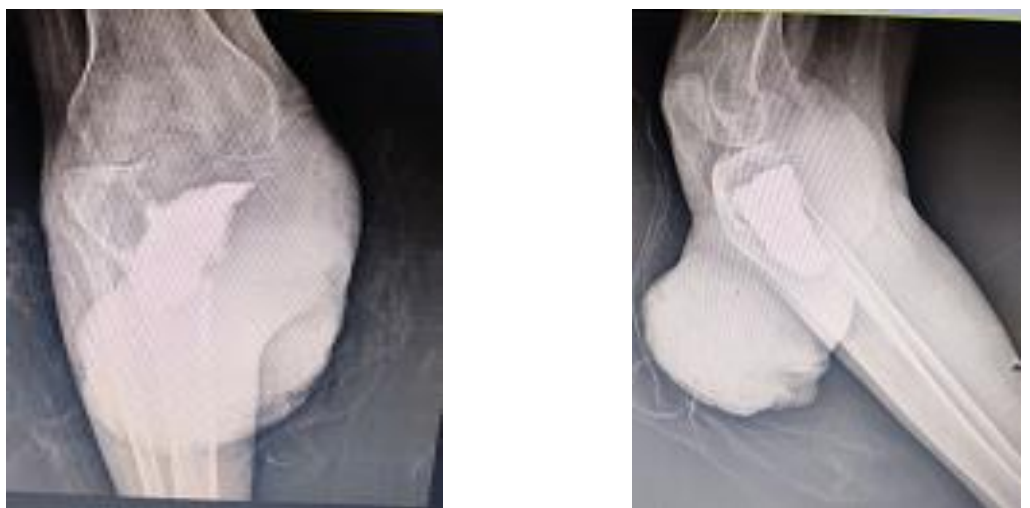

Fig 2: AP \& lateral view X-ray of right knee

CT imaging revealed loose expansile soft tissue lesion in metaphysis of proximal right tibia with soft tissue component (neoplastic etiology) aggressive.
Histopathological report suggestive of giant cell tumor of bone malignant type with plenty of giant cell, plenty of eosinophils and round oval stromal cells.
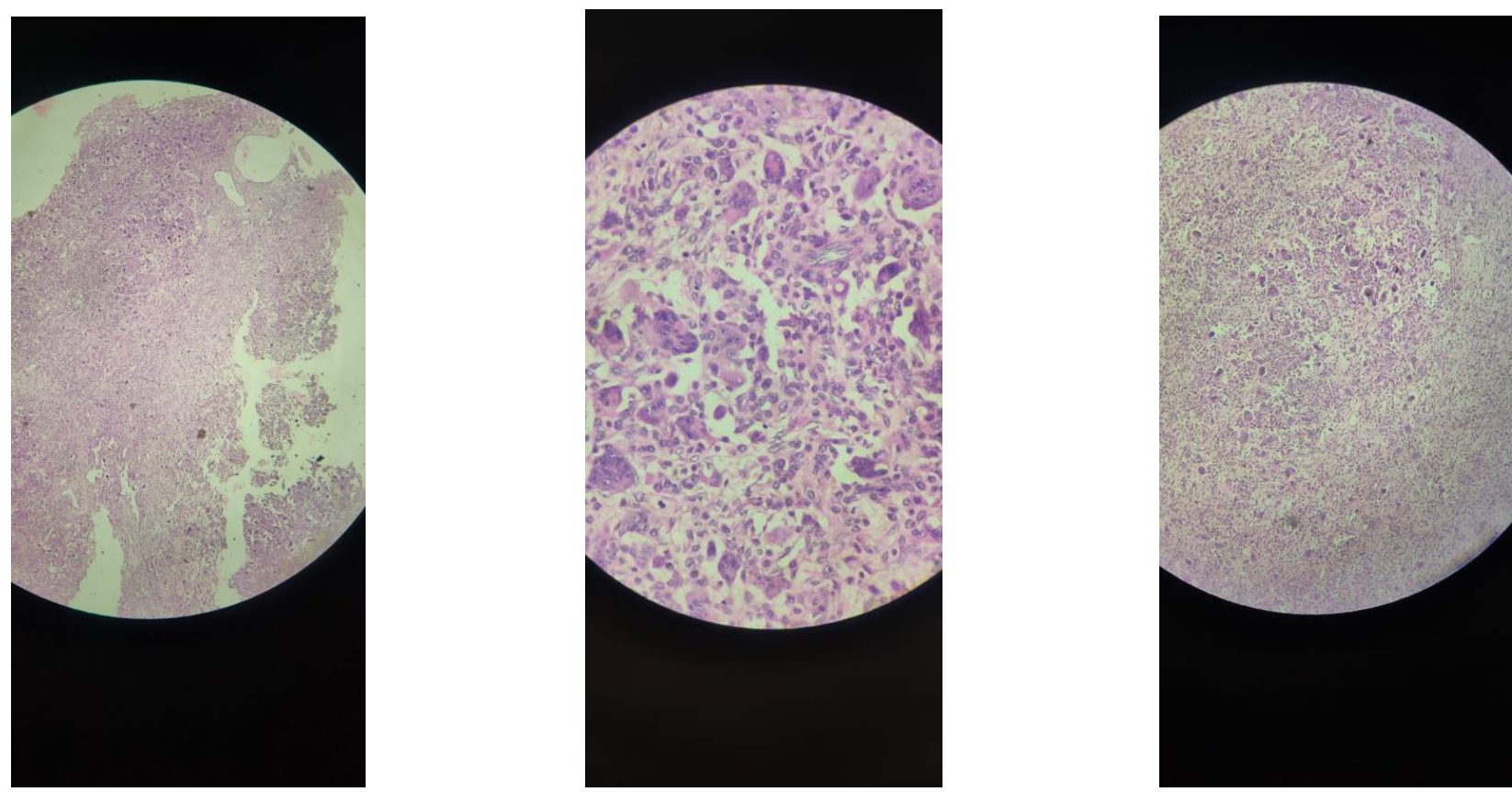

Histopathology slides of sent sample Magnetic resonance imaging revealed findings of recurrence of primary neoplasm. 

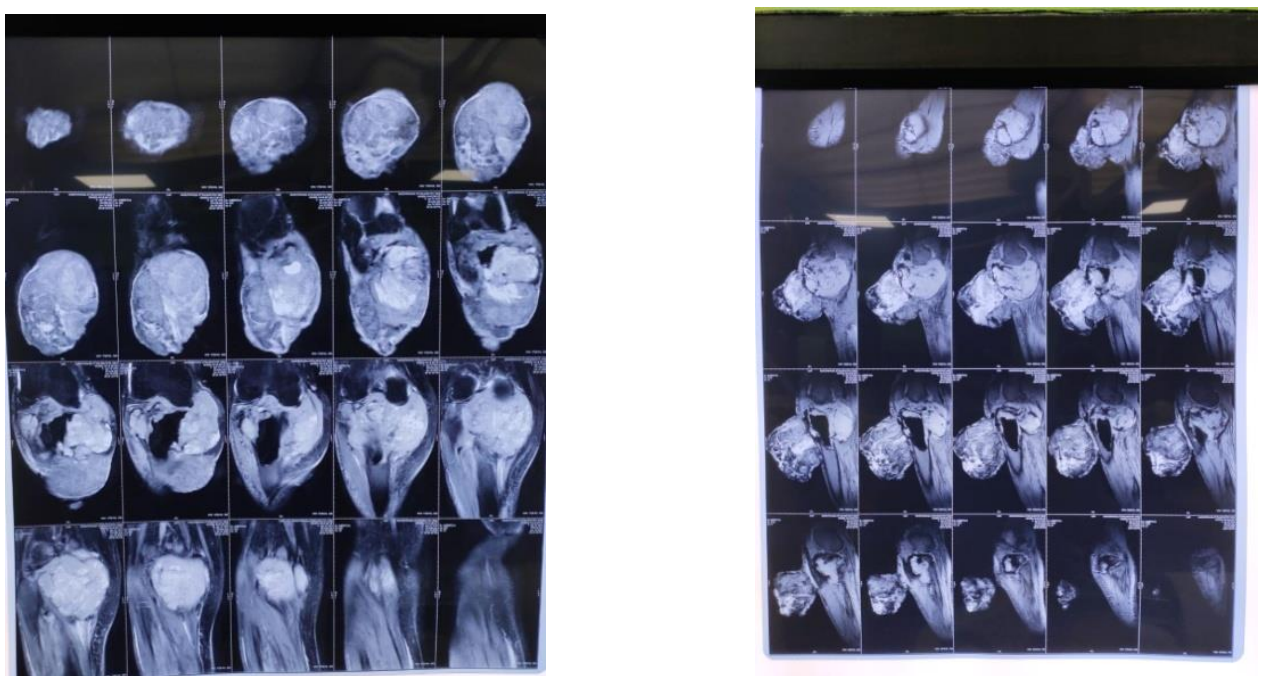

Fig 3: Magnetic resonance imaging

Surgery by amputation of right leg by knee disarticulation done to avoid recurrence. Laboratory investigations were within normal limits and surgery in the form of amputation was planned. The tumor was excised). The specimen was sent to histopathology for further examination. A thorough wash was given, and the defect was treated with $5 \%$ phenol. The tumor which was sent for histopathological examination which confirmed the diagnosis of GCT. Histopathology of the tissue showed malignant type of giant cell tumor.

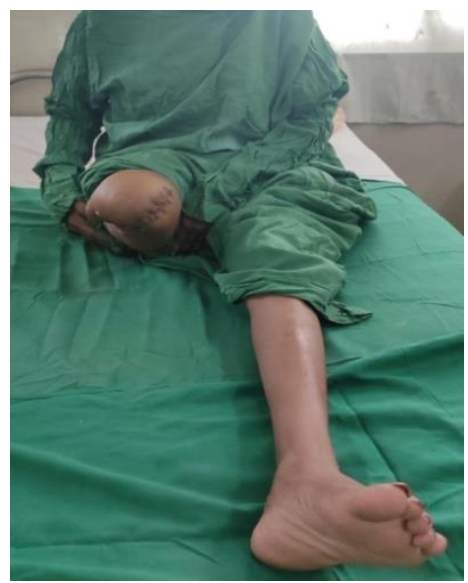

Fig 4: Post operation picture of patient Conclusion

The patient at 6 months follow-up is doing well, without any pain, comfortably and amputation stump movement present with no signs of recurrence. Hence, we conclude that a patient of recurrence case of GCT of proximal tibia was successfully treated with amputation. Giant cell tumors should be kept in mind as a differential diagnosis of all lytic lesions. Although they are known to occur in the distal femur, the proximal tibia, the distal radius, and the sacrum. excision, curettage, treatment of the lesion with phenol and finally filling with bone grafting and cementing gives excellent results and reduces the chances of recurrence but recurrence can occur as seen in our case with malignant fulminating mass where aggressive treatment like amputation may be needed.

Consent: The authors confirm that Informed consent of the patient is taken for publication of this case report
Financial support and sponsorship: Nil.

Conflicts of Interest: There are no conflicts of interest.

\section{References}

1. Turcotte RE. Giant cell tumor of bone. Orthop Clin North Am 2006;37:35-51. [PubMed] [Google Scholar]

2. Eckardt JJ, Grogan TJ. Giant cell tumor of bone. Clin Orthop Relat Res 1986;204:45-58. [PubMed] [Google Scholar]

3. McGrath PJ. Giant-cell tumour of bone: An analysis of fifty-two cases. J Bone Joint Surg Br 1972;54:216-29. [PubMed] [Google Scholar]

4. Bertoni F, Present D, Sudanese A, Baldini N, Bacchini $\mathrm{P}$, Campanacci M et al. Giant-cell tumor of bone with pulmonary metastases. Six case reports and a review of the literature. Clin Orthop Relat Res 1988;237:275-85. [PubMed] [Google Scholar]

5. Siebenrock KA, Unni KK, Rock MG. Giant-cell tumour of bone metastasising to the lungs. A long-term followup. J Bone Joint Surg Br 1998;80:43-7. [PubMed] [Google Scholar]

6. Hoeffel JC, Galloy MA, Grignon Y, Chastagner P, Floquet J, Mainard L et al. Giant cell tumor of bone in children and adolescents. Rev Rhum Engl Ed 1996;63:618-23. [PubMed] [Google Scholar]

7. Shih HN, Hsu RW, Sim FH. Excision curettage and allografting of giant cell tumor. World J Surg 1998;22:432-7. [PubMed] [Google Scholar]

8. Osaka S, Toriyama S. Surgical treatment of giant cell tumors of the pelvis. Clin Orthop Relat Res 1987;222:123-31. [PubMed] [Google Scholar]

9. Cribb GL, Cool P, Hill SO, Mangham DC. Distal tibial giant cell tumour treated with curettage and stabilisation with an ilizarov frame. Foot Ankle Surg 2009;15:28-32. [PubMed] [Google Scholar]

10. Canale TS. Campbell's Operative Orthopaedics. 11th ed. Ch. 21. Vol. 1. New York, NY, USA: Mosby, Benign/Aggressive Tumors of Bone; 2007. pp. 883-6. [Google Scholar]

11. Murphey MD, Nomikos GC, Flemming DJ, Gannon FH, Temple HT, Kransdorf MJ et al. From the archives of AFIP. Imaging of giant cell tumor and giant cell reparative granuloma of bone: Radiologic-pathologic 
correlation. Radiographics 2001;21:1283-309. [PubMed] [Google Scholar]

12. Carrasco $\mathrm{CH}$, Murray JA. Giant cell tumors. Orthop Clin North Am 1989;20:395-405. [PubMed] [Google Scholar]

13. Puri A, Agarwal M. Treatment of giant cell tumor of bone: Current concepts. Indian J Ortho p 2007;41:1018. [PMC free article] [PubMed] [Google Scholar]

14. Sandesh M, Sandeep V, Monappa N, Sharath R. Recurrent giant cell tumour of distal Tibia: Case report and review of the literature. Ann Med Biomed Sci 2015;1:4-7. [Google Scholar]

15. Bami M, Nayak AR, Shreepad K, Kulkarni A, Gupta R. Giant cell tumor of lower end of tibia. Case Rep Orthop 2013;2013:429615. [PMC free article] [PubMed] [Google Scholar] 